

\section{HAY AND PASTURE CROPS FOR ALBERTA}

This publication has been prepared by the Alberta Forage Crops Advisory Committee appointed by Honourable L. C. Halmrast, Minister of Agriculture.

\section{PERSONNEL OF COMMITTEE}

Dept. of Plant Science, University of Alberta, W. E. Smith (Chairman) Dept. of Plant Science, University of Alberta J. Unrau

Dept. of Soils, University of Alberta C. F. Bentley Field Crops Branch, Alberta Dept. of Agriculture, R. L. Pharis (Secy.) Field Crops Branch, Alberta Dept. of Agriculture A. M. Wilson Dominion Experimental Farm, Beaverlodge C. R. Elliott Dominion Experimental Farm, Lacombe

Dominion Experimental Farm, Lethbridge R. W. Peake Science Service, Canada Dept. of Agriculture J. B. LeBeau Plant Products Division, Canada Dept. of Agriculture L. B. Goodall Seed Trade Representative J. A. Robertson Seed Growers' Co-operatives Representative R. B. Frankish

\section{EDITORIAL COMMITTEE}

R. L. Pharis, Chairman

H. B. Stelfox*

C. F. Bentley

C. R. Elliott

W. E. Smith

R. W. Peake

* Deceased April 1, 1957. 


\section{INDEX}

The Value of Forage Crops ……… 3

Use of Fertilizer

Legume Inoculation _....... 7

Choosing The Crop ……… 8

Suggested Mixtures of Grasses and Legumes .................. 9

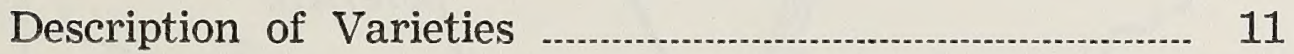

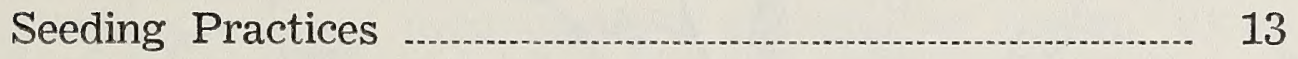

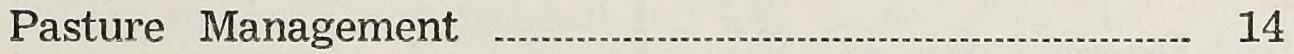

Management of Hay Crops …...................... 18 


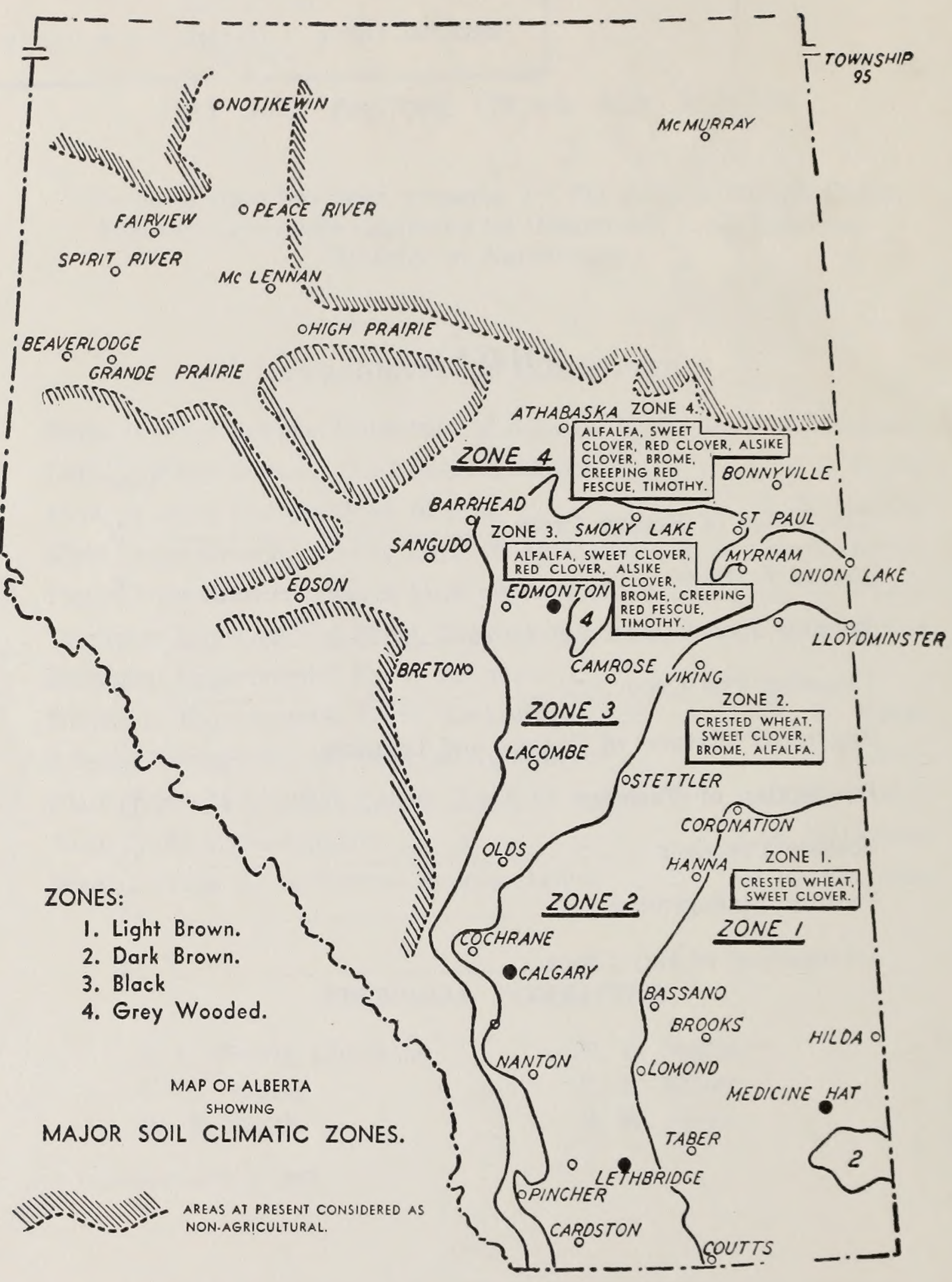




\section{HAY AND PASTURE CROPS FOR ALBERTA}

\section{THE VALUE OF FORAGE CROPS}

Forage crops are the basis of permanent agriculture and have a place on every Alberta farm. The benefits from inclusion of forage crops in the cropping system are many and varied. They prevent both wind and water erosion by tying the soil down. They provide one of the best known methods of weed control. Good yields of grain crops are dependent on suitable soil tilth and fertility; forage crops are the only Alberta crops which can improve soils in these respects. Soil tilth is improved by the fibre left in the soil by grasses and by the deep penetrating roots of alfalfa and sweet clover. Bacteria on the roots of properly inoculated legumes take nitrogen from the air which is converted to protein in the plants; the superior feed value of legumes is due to the high protein content which results. Cereals grown on land broken from alfalfa or clover yield better and have a higher protein content because of the rich residues left in the soil by these legumes. Thus rotating forage crops with grain crops provides an excellent source of livestock feed and prepares the land for grain crops to follow.

Forage crops are widely adapted in Alberta as there is a grass or legume suited to nearly every location and soil type. In addition to field production, there are areas on every farm such as watercourses, low spots, field margins, and roadsides where forage crops can be produced.

Where you live will decide how much of your land should be seeded to grass and legume crops at any one time. The map on the opposite page will show the zone in which you are living and the kinds of forage crops suitable for your district. Keep in mind that the lines between the zones are not clear cut.

Cropping practices and forage species recommendations for the various soil zones are discussed in the following sections.

\section{ZONE 1}

Rainfall is light and, except on eroded soils, fertility appears to be fairly well maintained even under a grain-fallow system. Fibre can also be maintained by trash-cover farming which keeps as much straw and stubble as possible in the soil surface. Implements that will maintain a trash cover are essential for farming in this zone.

Regular rotations of grain and forage are rarely followed in Zone 1. With the low rainfall, soil fertility declines slowly and it is often difficult to establish forage stands. Forage crops do have a place in this area. They contribute to a more balanced type of farming, prevent soil erosion and improve soil structure. A portion of the cultivated land might well be sown to grass periodically and left down for about five years. Crested wheat grass is widely used, particularly for regrassing overgrazed ranges and for permanent seeding down of light soils that tend to drift readily. The grazing capacity of a good stand of Crested wheat grass is considerably greater than that of native range.

Sweet Clover is also useful in this zone, since it adds nitrogen to the soil. It should be seeded with the last grain crop before summerfallow. 


\section{ZONE 2}

Better moisture conditions in this zone mean more rapid soil depletion and a greater need for forage crops. Crested wheat grass and sweet clover will be the choice in the drier sections. In districts of more plentiful moisture, alfalfa and brome grass may be grown to advantage. Throughout this zone, greater use should be made of sweet clover to improve soil fertility through its ability to take nitrogen from the air.

Land should not be seeded to a cereal crop if more than eight to twelve years have elapsed since it was last down to a forage crop.

Forage crops should remain down from three to five years. If a satisfactory stand is established in the first year, three years of forage may be sufficient.

\section{IRRIGATED AREAS}

In the irrigated areas the more abundant water supply calls for increased use of forage crops. Not more than four or five grain crops should be grown in succession without a return to grasses or legumes. However, the readily available water offers a wider choice in selection of these crops.

Alfalfa is the main hay crop since it fits well into most farm programmes on irrigated land. Brome, creeping red fescue, timothy, Kentucky blue grass, orchard grass and the clovers, all thrive under irrigation.

Forage should remain down from four to six years depending on the kind of mixture used and the density of the stand. A good stand will benefit the soil more quickly than a poor one. Summerfallowing should not be necessary on irrigated land. A suitable crop rotation consisting of grain or specialty crops and forage crops should enable the production of a crop every year while at the same time weeds are controlled and the soil improved.

\section{ZONE 3}

Land that is more than five to eight years away from forage should not be seeded to grain in this zone. Alfalfa and brome grass are the most useful forage crops, but all winter hardy grasses and legumes can be grown successfully. The most important of these are altaswede (red) clover, alsike clover, timothy, and creeping red fescue. Creeping red fescue may be used to advantage since its extensive root system will add large amounts of fibre to the soil.

Forage crops in Zone 3, should remain down from two to four years, depending on the kind of mixture used and the density of the stand. If a good stand is obtained in the year of seeding the desired soil improvement will take place quickly.

\section{ZONE 4}

In this zone-the grey-wooded-land that is more than two to four years away from forage should not be seeded to grain. Legumes must be grown if the land is to yield profitable returns. Since, under natural conditions, the soil contains very little fibre, grasses are essential too. Alfalfa and the clovers, brome, timothy and creeping red fescue are all important forage crops in this area. 


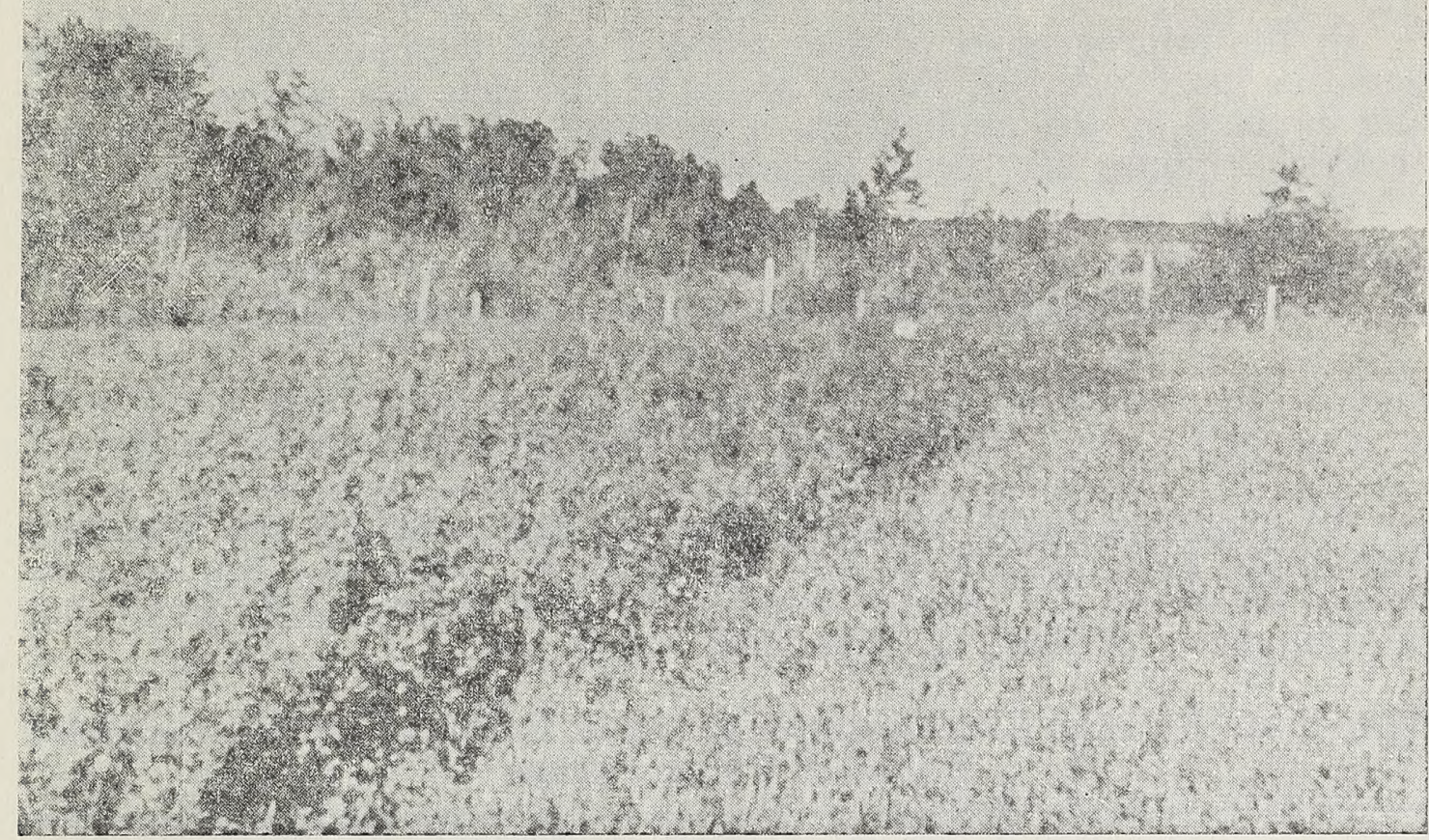

Clover on grey-wooded soil - Breton area

Fertilized

Unfertilized



Wheat on grey-wooded soil - Breton area After Fertilized Clover. After Unfertilized Clover. 
Forage should remain down from two to three years, depending on the kind of mixture used and the condition of the crop. A good stand will improve the soil more quickly than a poor one.

In the improvement of grey-wooded soils, legumes and fertilizers should be used together. Forage yields in this zone are commonly more than doubled by the application of fertilizer. Yields of grain following fertilized legumes also show remarkable increases.

Sulphur, nitrogen and phosphate are the main elements usually lacking. Nitrogen can be supplied by growing legume crops but sulphur and phosphate must be supplied in the form of commercial fertilizer.

\section{USE OF FERTILIZER}

An adequate supply of plant nutrients and moisture are necessary to promote good growth of hay and pasture crops. The use of commercial fertilizer will usually boost production substantially in all but the drier parts of Alberta. (See table below).

\section{Three-Year Average Yield Results for use of Fertilizer at Recommended Rates on Forage Crops}

\begin{tabular}{|c|c|c|c|c|c|}
\hline \multirow{3}{*}{\multicolumn{2}{|c|}{ Fertilizer Used }} & \multirow{2}{*}{$\begin{array}{l}\text { Grass on } \\
\text { Black } \\
\text { Medium } \\
\text { Loam Soil }\end{array}$} & \multirow{2}{*}{$\begin{array}{l}\text { Legume on Sulphur } \\
\text { Deficient Grey } \\
\text { Wooded Soil }\end{array}$} & \multicolumn{2}{|c|}{$\begin{array}{l}\text { Grass-Legume Mixture } \\
\text { on Black Soil } \\
\end{array}$} \\
\hline & & & & Sandy Loam & Heavy Loam \\
\hline & & \multicolumn{4}{|c|}{ Yield Increase Due to Fertilizer Treatment } \\
\hline \multicolumn{2}{|c|}{ lb./Ac. } & & $\begin{array}{l}\text { Tons of Hay } \\
\text { per Acre }\end{array}$ & & \\
\hline $21-0-0$ & 62 & .25 & 1.68 & $\cdots$ & $\ldots$ \\
\hline $33-0-0$ & 100 & .64 & -.... & $.44 *$ & $.15^{*}$ \\
\hline $16-20-0$ & 100 & .40 & 1.75 & .80 & 1.06 \\
\hline $11-48-0$ & 85 & .20 & .89 & .31 & .85 \\
\hline $\begin{array}{l}\text { Yield With } \\
\text { Fertilizer }\end{array}$ & & 1.10 & 1.33 & .91 & 1.10 \\
\hline
\end{tabular}

- 200 pounds per acre 33-0-0 used in these tests instead of 100 pounds.

\section{When to Apply Fertilizer}

1. On sulphur-deficient grey wooded soil, fertilizing at or just prior to seeding helps to establish strong stands of legumes. On most other soils, it is usually more profitable to fertilize the second and subsequent years.

2. Applications are best made early in the spring.

\section{How to Apply Fertilizer}

A variety of equipment can be used including combination fertilizer-seed drills, fertilizer attachments for grain drills and broadcast spreaders.

Do not mix inoculated legume seed with fertilizer. The fertilizer may harm the nitrogen-fixing bacteria and fertilizer sticking to the moist seed may lower germination. 


\section{Fertilizer Needs}

It is important to use the right fertilizer on the right crop. The need varies with the soil and the crop. In general there is a need for phosphorus, especially for legumes and grass-legume mixtures. Grasses also require nitrogen. Legumes may require sulphur when grown on grey soils. Recommendations for fertilizing hay and pasture crops are given below.

\section{Recommended Rates of Fertilizer Application (Pounds per Acre)}

\begin{tabular}{|c|c|c|c|}
\hline Fertilizer Analysis & $\begin{array}{l}\text { Dark Brown (1), } \\
\text { Black and Degraded } \\
\text { Black Soils }\end{array}$ & $\begin{array}{l}\text { Grey Wooded } \\
\text { Soils (2) }\end{array}$ & $\begin{array}{l}\text { Irrigated } \\
\text { Land }\end{array}$ \\
\hline & Legumes & nd Grass-Legume & Mixtures \\
\hline $11-48-0$ & $50-150$ & -........ & 100 \\
\hline $16-20-0$ & $100-200$ & $50-150$ & 100 \\
\hline $21-0-0$ & ......... & $50-150$ & -...-.. \\
\hline Other sulphur fert. & -....... & 20 lbs. S. & -..... \\
\hline & Grasses or Mixture & with Less than $10^{\circ}$ & 6 Legume in Stand \\
\hline $27-14-0$ & $100-200$ & $50-150$ & 125 \\
\hline $16-20-0$ & $100-200$ & $50-150$ & 125 \\
\hline $33.5-0-0$ & $100-200$ & $50-150$ & 100 \\
\hline $21-0-0$ & $150-300$ & $75-200$ & 150 \\
\hline
\end{tabular}

(1) Suggested for use on a trial basis in this zone.

(2) As yet there is no recommendation to fertilize legumes and grass-legume mixtures grown on grey soils in the Peace River area.

\section{Farm Manure}

This is one of the best fertilizers. It supplies not only plant nutrients, but when applied on hay and pasture fields it acts as a mulch in conserving moisture. Farm manure is recommended for use in all soil zones. It should be spread evenly at a rate of 10 to 15 tons per acre. Manure is rather low in phosphate, so phosphate fertilizers generally should be used with it for best results.

Note: For more detailed information see Publication No. 5, "Fertilizers in Alberta."

\section{LEGUME INOCULATION}

1. Legumes must be inoculated if the full value of these crops to the land is to be realized. Inoculation makes it possible for nitrogen to be taken from the air and to be fixed in the soil.

2. Inoculation consists merely of treating the seed with cultures of suitable bacteria. Cultures are low in cost and easy to apply. They may be obtained from your local store.

3. There are several kinds of legume bacteria, each capable of inoculating a special group of legumes. Farmers producing forage crops 
in Alberta are interested in two of these groups: (a) the alfalfa group which is also used for inoculating sweet clover; and (b) the red clover group which is capable of inoculating red, alsike, and white Dutch clover. "Double seeded" cultures have given good results. These contain two kinds of bacteria; one capable of inoculating the alfalfa group of legumes and the other the red clover group. Look for the date on the container. Cultures are dated and not guaranteed effective after the date shown.

\section{CHOOSING THE CROP}

The importance of choosing the right crop for a particular area or location cannot be too strongly emphasized. The following table indicates soil and climatic conditions to which various forage species are adapted.

\section{LEGUMES \\ *Rate of Seeding - lbs. per Acre}

Alfalfa -8 to 10 -Prefers moist but well-drained soils. Unequalled as a forage crop.

Alsike - 5 to 6 -Useful where moisture is adequate; on low lands, in areas subject to flooding, and in the cooler, irrigated areas.

Red Clover (Altaswede) - 7 to 8-Adapted generally to the greywooded and black soils.

Sweet Clover -8 to 12 -Wide adaptation. Especially useful on alkaline and clay soils. Sweet clover weevil may be a problem in some areas.

\section{GRASSES}

Brome - 10 to 12-Adapted to wide range of moisture conditions. Makes good growth throughout the summer.

Creeping Red Fescue -6 to 8-A useful grass except where moisture is limited. Good pasture from spring to late fall. Extensive root system.

Crested Wheat - 6 to 10 -Thrives on the dry, open plains, and on sandy soils in other areas. Makes early spring and late fall growth. Extensive root system.

Timothy -5 to 6 -Likes rich, moist soils and cool temperatures. Stands are short lived.

Slender Wheatgrass - 10 to 12 -Useful for alkali salty and spring flooded land. Fair hay and pasture. Stands are short lived.

Reed Canary Grass - 6 to 8-Very tolerant of flooding. Good pasture, coarse hay. Develops a tough sod.

Orchard Grass - 10 to 12 -An excellent grass under irrigation. May winter kill farther north.

Tall Wheatgrass - 10 to 12 -Useful for wet, alkaline soils. Makes fair hay or pasture.

* In very dry areas, not over half the maximum rates given above should be used, and rows should be twice as far apart, e.g., crested wheatgrass should be seeded at 3 to 5 pounds per acre in rows 12" to 14" apart. 


\section{SUGGESTED MIXTURES OF GRASSES AND LEGUMES}

\section{Grow Mixtures}

alone.

Mixtures have several advantages over grasses or legumes sown

1. Legumes increase the feeding value and bulk of the mixture, and since they add nitrogen to the soil they help maintain soil fertility.

2. Grasses fill the soil with needed root fibre. When grown with legumes they furnish hay that is easier to cure, and pastures from which there is less danger of bloating.

3. Mixtures are higher yielding than pure species and remain productive for a longer period of time. They also provide better seasonal distribution of herbage.

4. They are adapted to a much wider range of soil and moisture conditions than either a single grass or a single legume species.

Two exceptions to the above should be noted, however. Under Irrigation, Ladak or Vernal alfalfa grown alone is the preferred hay crop, and in extremely dry locations, crested wheat grass is the most satisfactory forage crop.

In the following table, figures refer to pounds of seed per acre.

\section{FOR PASTURE}

\section{Mixture}

1. Alfalfa

Brome

Creeping Red Fescue

2. Alfalfa

Brome

3. Alfalfa

Crested Wheat

Brome

4. Crested Wheat

5. Brome

Ladak or Vernal Alfalfa

6. Brome

Creeping Red Fescue

Orchard Grass

White Dutch

7. Altaswede Red Clover Alsike

White Dutch

Creeping Red Fescue

Timothy
Adaptation

$2-3$

6 For all but drier parts fo the province.

3

$\left.\begin{array}{l}3 \\ 8\end{array}\right\}$ Zones 2 and 3.

$\left.\begin{array}{l}3 \\ 3 \\ 6\end{array}\right\}$ Zones 2 and 3

3-5 For hay or pasture in very dry areas.

$\left.\begin{array}{r}12 \\ 2\end{array}\right\}$ Short-term pasture under irrigation.

7
4

2)

Long-term pasture under irrigation.

1 Recommended for moist sections of Zone 4.

2 Use No. 1 mixture in other parts of 3 ) 


\section{FOR PASTURE OR HAY}

\section{Mixture}

1. No. 1 Pasture Mixture

2. Alfalfa

Brome

Crested Wheat

3. Alskike

Reed Canary

4. Alsike

Red Top

\section{Adaptation}

\} For all but the drier parts of province.

3 For Zones 2 and 3 and where moisture 5 conditions are variable. 3)

2 Suited to wet locations subject to 5 flooding.

$\left.\begin{array}{l}2 \\ 5\end{array}\right\}$ For acid soils subject to flooding.

\section{FOR HAY}

\section{Mixture}

1. Alfalfa

Brome

2. Alfalfa

Crested Wheat

3. Alfalfa

Brome

Crested Wheat

4. Alfalfa

Timothy

5. Red Clover

Brome

6. Red Clover

Timothy

7. Alsike

Timothy

8. Elsike

\section{Reed Canary}

9. Ladak or Vernal Alfalfa alone

\section{Adaptation}

5 Recommended for same areas as No. 1 6) Pasture Mixture.

3 For Zones 2 and 3 and where moisture 5 conditions are variable.

$\left.\begin{array}{l}5 \\ 3\end{array}\right\}$ Areas of plentiful moisture.

5) Grey-wooded or black soil areas of 6) plentiful moisture.

5 Grey-wooded or black soil areas of 3 plentiful moisture.

$\left.\begin{array}{l}4 \\ 3\end{array}\right\}$ Wet locations subject to flooding.

$\left.\begin{array}{l}4 \\ 3\end{array}\right\}$ Areas subject to prolonged flooding.

8-10 Preferred hay crop in irrigated areas.
6\} For Zones 2 and 3.

By adding up to 4 pounds of sweet clover to a mixture and reducing slightly the amount of other legumes used, a greater yield of forage will be obtained in the year after seeding. Since sweet clover is a biennial, it will disappear after the second year unless allowed to reseed. 
Hay Yields in Tons per Acre at Lacombe, Alberta

\begin{tabular}{|c|c|c|c|}
\hline \multirow[b]{2}{*}{ Species or Mixture } & \multicolumn{2}{|c|}{1937 Seeding } & 1941 Seeding \\
\hline & $\begin{array}{l}3 \mathrm{Yr} \text { Av. } \\
(1938-40)\end{array}$ & $\begin{array}{l}5 \text { Yr. Av. } \\
(1938-42) \\
\end{array}$ & $\begin{array}{l}3 \text { Yr. Av. } \\
(1942-44) \\
\end{array}$ \\
\hline Crested wheatgrass & 1.88 & 1.37 & 1.66 \\
\hline Timothy & 1.32 & 1.06 & 1.79 \\
\hline Brome & 2.23 & 1.77 & 2.10 \\
\hline Alfalfa & 1.92 & 1.80 & 1.79 \\
\hline Alfalfa and Crested wheat & 2.09 & 1.92 & 2.02 \\
\hline Alfalfa and timothy & 1.88 & 1.80 & 2.45 \\
\hline Alfalfa and brome & 2.29 & 2.09 & 2.26 \\
\hline
\end{tabular}

Experimental Farm, Lacombe.

\section{TABLE 2}

Hay Yields in Tons per Acre on Daysland Loam at Ankerton, Alberta (Zone 3 near Zone 2 border)

\begin{tabular}{|c|c|c|c|c|}
\hline Species or Mixture & 1952 & 1953 & 1954 & $3 \mathrm{Yr}$. Average \\
\hline Crested wheatgrass & .92 & .97 & 1.02 & .97 \\
\hline Brome & 1.13 & .90 & 1.05 & 1.03 \\
\hline Intermediate wheatgrass & 1.28 & .98 & 1.19 & 1.15 \\
\hline Crested wheat \& Alfalfa & 1.35 & 1.82 & 1.76 & 1.64 \\
\hline Brome and Alfalfa & 1.54 & 1.31 & 1.75 & 1.53 \\
\hline Intermediate wheat \& Alfalfa & 1.66 & 1.35 & 1.83 & 1.61 \\
\hline Brome, crested wheat \& alfalfa & 1.44 & 1.37 & 1.73 & 1.51 \\
\hline $\begin{array}{l}\text { Brome, crested wheat, alfalfa, } \\
\text { sweet Clover }\end{array}$ & 1.77 & 1.40 & 1.69 & 1.62 \\
\hline
\end{tabular}

Experimental Farm, Lacombe

\section{DESCRIPTION OF VARIETIES}

GRIMM ALFALFA is a hardy variety that has proven satisfactory in all areas of Alberta except where bacterial wilt has been a problem. Grimm is susceptible to bacterial wilt. It is generally lower in yield than are Ladak and Vernal.

LADAK ALFALFA is more winter hardy and higher in forage yield than Grimm and has some resistance to bacterial wilt. Ladak produces a higher yield from the first cutting than does Grimm.

VERNAL ALFALFA is equal or superior to Ladak in winter hardiness and forage yield. It is resistant to bacterial wilt and because of 
this is more suitable for irrigated areas than are the varieties Grimm and Ladak.

RAMIBLER ALFALFA is similar in yield to Ladak and Vernal and possesses greater hardiness than Ladak. The creeping-rooted characteristic makes it promising as a pasture alfalfa. Seed of this variety is not yet available in commercial quantities.

ARCTIC SWEET CLOVER is the standard white blossomed sweet clover for western Canada. It was selected out of Common White for its winter hardiness, medium fine stem, leafiness and high forage yield. It is a few days earlier in maturity than Common White. In widely distributed tests Arctic has yielded as much or more hay than any other variety in test during the last twenty years.

ERECTOR SWEET CLOVER is much more uniform and somewhat more erect than than Common Yellow. It is finer stemmed than Arctic and blooms approximately a week earlier. The yield for hay has been generally similar to that for Arctic but on a few stations in western Canada Erector has out-yielded Arctic.

ALTASWEDE is a single-cut red clover. It is a tall-growing, late maturing, high-yielding variety with moderate resistance to disease. Altaswede blooms approximately 12 days later than Lasalle. Its average yield at Lacombe for the three-year period, 1953-55, has been 3.29 tons of hay per acre.

LASALLE is a double-cut red clover. Lasalle is appreciably less winter hardy than Altaswede; a factor which accounts for its lower production of forage in the central and northern parts of Alberta. It produced 9\% less forage than Altaswede over the three-year period, 1953-55, at Lacombe. The growing of Lasalle in Alberta should be limited to its production as a seed crop.

FAIRWAY CRESTED WHEATGRASS is a shorter-growing, finer stemmed and more leafy form than the Standard type of Crested wheatgrass. The Fairway variety predominates in the seed trade of Crested Wheatgrass in Canada and is the variety generally grown at present on farms. It is unexcelled as a pasture grass for the drier areas of western Canada and has performed well as pasture and as hay in the parkbelt region. Fairway is a relatively short grass for hay. Young stands grow 2 feet high and older stands 1 foot or less. Yield of hay compares well with that of brome grass but quality of hay as judged by protein content is slightly below that of brome grass.

SUMMIT is a high yielding variety of the Standard type of Crested Wheatgrass. On the basis of extensive hay tests throughout western Canada, Summit has yielded $10 \%$ more hay than Fairway. It grows 3 to 4 inches taller than Fairway and this height advantage is especially noticeable in old fields. Summit has performed particularly well in alfalfa mixtures and does not crowd alfalfa out of mixtures as does the Fairway variety. Limited chemical analyses indicate the feeding value of this variety to be equal to Fairway. In moist districts Summit has suffered more winter killing in old stands than has the Fairway variety.

CLIMAX TIMOTHY is a tall-growing, upright, relatively finestemmed variety. It is quite leafy, with the leaves carried high on the stems. This variety is approximately seven days later maturing than common timothy. It has considerable resistance to leaf-spot and timothy 
rust. Climax has given good performance from a yield standpoint. Hay and pasture yields have averaged between $10 \%$ and $15 \%$ higher than those of common timothy and the hay is generally of superior quality, due to the leafiness of the variety. The aftermath growth in some localities has been exceptional, which is a desirable characteristic from the standpoint of pasture production.

OLDS CREEPING RED FESCUE is a perennial turf grass with a dense, fibrous, creeping root system, but it is not as difficult to eradicate as are some other grasses with creeping roots. It forms a dense turf that stands severe trampling without injury. The leaves are narrow, folded and have a dark green colour which is retained into the winter. Olds is primarily a pasture species and should not be considered seriously for hay production.

\section{SEEDING PRACTICES}

\section{Time to Seed}

The time of seeding will depend on the moisture conditions of your area.

1. In the brown soil zone, early fall seeding is best for grassesfrom the third week in August until the middle of September. Alfalfa may be seeded into stubble immediately after harvest but not later than mid-August. If legumes are sown in the early fall they are almost certain to be winterkilled. Either grasses or legumes may be seeded in early May. Crested Wheat grass may also be sown just before freezeup in the very dry areas. A hazard in early fall seeding is grasshoppers, which will move from grain crops to green growth. Forage crops should not be sown on land that is known to be infested with cutworms.

2. In areas of more adequate moisture, as in the black and greywooded soil zones, early spring seeding is not so necessary. If moisture is adequate, seeding may be delayed as late as mid-June. If legumes or grass-legume mixtures are sown late in the fall, it should be just before freeze-up.

3. Do not seed unless there is enough moisture at the depth of planting to germinate the seed. It is better to keep the seed in the sack than to seed in loose, dry soil.

\section{Companion (or Nurse) Crops}

A companion crop is not recommended in the drier areas, and even where moisture is plentiful, there is a risk of losing the forage seeding.

When using a companion crop the following should be considered:

1. In land that is not weedy, flax is the best of all companion crops, except on irrigated land where it depresses the forage stand.

2. Early varieties of barley and oats may be used as companion crops if seeded at not more than one-half the usual rate. If late varieties are used they should be seeded at about one-half bushel per acre and cut for green feed.

\section{Seeding}

1. Seed should be sown into a MOIST FIRM seed bed no deeper than one-half inch except brome which can be sown to a depth of one inch. 
2. Unless soil will bake, packing before and after seeding of forage crops is usually advisable.

3. A firm seed bed can best be achieved on stubble land by seeding into the stubble without cultivation. Stubble seeding also protects the young plants against wind and water erosion.

4. If cultivation is needed for weed control, it should be shallow and followed by packing.

5. A special forage seeder is a wise investment if it is planned to sow a large acreage of forage or if the rotation plan calls for forage seed each year.

6. A grass seeder attachment for the grain drill is satisfactory for the smaller seeds. Good heavy seed of Creeping Red Fescue and crested wheat will seed through the attachment when mixed with legume seed.

7. Brome and light or poorly prepared seed of creeping red and crested wheat may bridge over drill cups. This can be avoided by mixing with cereal seed, cracked wheat or screened coal.

8. When forage seed is sown directly through the main drill box, depth adjustments must be made so the seed is not placed too deeply.

9. Broadcasting of seed seldom results in as satisfactory stands as does other methods. Broadcasting should only be done where it is impossible to use the drill.

10. Established grass-legume mixtures are very effective in weed control, but land that is heavily infested with perennial weeds should be summer-fallowed for a full year before seeding.

\section{Care After Seeding}

1. Do not allnw over grazing of the forage planting, especially the year after planting.

2. Clip the weeds from new plantings if weed growth is heavy.

3. Broad leafed weeds susceptible to 2, 4-D can be controlled in grass seedings by spraying with recommended rates of this chemical.

4. Legume seedings should not be treated with 2, 4-D because they are affected by this chemical.

5. M.C.P., a compound similar to 2, 4-D has proved to be less injurious to alfalfa, alsike and red clover. M.C.P. at 2 to 4 ounces per acre can be used on strong stands of these crops to control susceptible broad leafed weeds.

6. Sweet clover should not be treated with either 2, 4-D or M.C.P.

\section{PASTURE MANAGEMENT}

\section{Management of Native Permanent Pastures}

Improvement of native pastures that are rough and untillable is limited to:

1. Chemical control of weeds.

2. Applications of manure and fertilizer.

3. Control of time and rate of grazing.

4. Where possible it may be advisable to drill forage seed into the sod when the ground is moist. 
5. Carrying capacity of the short grass prairie area could be increased by drilling crested wheat into the sod. Seeding rate would depend on how quickly improvement was desired.

\section{Management of Seeded Pastures}

1. Mixtures suitable for pastures and recommended seeding and fertilizing practices have been given on pages $6,7,9$ and 13 of this bulletin. Mixtures of grasses and legumes are suggested because:

a. carrying capacity is increased;

b. legumes in the mixture prevent grass stands from becoming sod-bound (nitrogen deficient) so quickly.

2. Five or six years is usually the extent of the productive life of most seeded pastures. It is usually advisable to plow up older pasture stands and devote the land to other crops. Following a definite rotation plan of cereals and forage crop as suggested on pages 3 and 4 will aid in soil improvement.

3. Pasture stands will not be renewed or improved by cultivation alone. When production declines the pasture can be worked with a variety of implements such as the disc harrow, one way or cultivator. Reseeding and fertilization must accompany this surface cultivation if any lasting benefit is to occur.

4. Pasture plantings can be grazed late the first year if care is used not to overgraze or leave animals on the field when the ground is moist and damage would occur from trampling.

5. Grazing of established stands should not begin in the spring until growth is 8-10 inches high. Cattle should be removed when the pasture has been grazed to an average height of approximately three inches. Growth above three inches should then be clipped off and put up as silage or hay, or it can be clipped and left on the field.

6. More profitable returns from pastures can be realized through controlled rotational grazing than by any other single practice. Alternate grazing of two or three fields provides the plants with periods of rest and recovery. Avoid overgrazing at all times, particularly in the early spring and fall.

7. Pastures should be harrowed to spread droppings and applied barn yard manure.

8. Gophers and other rodents should be kept under control. Yields are reduced and their burrows are a hazard to stock.

9. Any succulent forage may cause bloat in sheep and cattle. Young, succulent legumes are especially likely to cause bloat, and alfalfa is usually considered the worst offender. Alfalfa is very palatable, grows quickly and tall, and retains its soft and succulent nature up to the blooming stage. Even in a mixture with grass, livestock will readily sort it out and may get too much. In spite of this, legumes including alfalfa, should be widely used in pasture mixtures. Where proper management is practised, losses from bloat are rare.

In the United States Department of Agriculture Farmers' Bulletin No. 1973, an excellent list of bloat prevention methods are listed as follows:

a. Let no more than $35 \%$ to $40 \%$ of the permanent pasture stand consist of legumes.

b. Keep salt and water readily available at all times. 
pasture.

c. Partially fill animals with hay before turning them on legume

d. Keep hay or straw in a manger in every legume pasture.

e. In localities where the bloat hazard is considered serious, allow pastures preponderantly of legumes to reach a fairly advanced stage of growth before turning stock on them.

f. Give bloated animals antiferment treatments, such as $1 / 2$ ounce of formalin or 1 ounce of turpentine as a drench. Mix formalin with water and turpentine with milk. or knife.

g. In severe cases, puncture the distended stomachs with a trocar Table 3

\section{Production from Seeded Pastures at Lacombe}

(Four-year Averages, 1952-55)

\begin{tabular}{|c|c|c|}
\hline Species or Mixture & $\begin{array}{l}\text { Tons of Dry } \\
\text { Matter Forage } \\
\text { per Acre }\end{array}$ & $\begin{array}{l}\text { Pounds of Beef } \\
\text { per Acre }\end{array}$ \\
\hline Creeping Red Fescue & 1.17 & 213 \\
\hline Brome & 1.14 & 208 \\
\hline Timothy & .97 & 177 \\
\hline Alfalfa and creeping red fescue & 1.13 & 206 \\
\hline Alfalfa and brome & 1.28 & 234 \\
\hline Alfalfa and timothy & 1.13 & 206 \\
\hline Alfalfa, brome \& creeping red fescue & 1.32 & 240 \\
\hline Alfalfa, timothy \& creeping red fescue & 1.17 & 214 \\
\hline
\end{tabular}

* Calculated on basis of 11 pounds dry matter forage required to maintain a steer and produce a pound of beef.

Experimental Farm, Lacombe.

\section{Table 4}

Summary of Four Years' Performance of Fertilized Pasture, 1953-56 (Peace River Grey Wooded Soil)

\begin{tabular}{|c|c|c|c|c|}
\hline $\begin{array}{l}\text { Species or } \\
\text { Mixture }\end{array}$ & $\begin{array}{l}\text { Fertilizer } \\
\text { treatment }\end{array}$ & $\begin{array}{l}\text { Rate per acre } \\
\text { in lbs. }\end{array}$ & $\begin{array}{l}\text { Average forage } \\
\text { yields, tons } \\
\text { dry matter/A }\end{array}$ & $\begin{array}{c}\text { Average } \\
\text { animal gains } \\
\text { in lbs./A }\end{array}$ \\
\hline $\begin{array}{l}\text { Creeping red } \\
\text { fescue }\end{array}$ & $\begin{array}{c}\text { nil } \\
11-48-0 \\
33-0-0\end{array}$ & $\begin{array}{l}300 \\
100\end{array}$ & $\begin{array}{r}.53 \\
1.41 \\
1.31\end{array}$ & $\begin{array}{r}86 \\
166 \\
151\end{array}$ \\
\hline $\begin{array}{l}\text { Fescue plus } \\
\text { alfalfa }\end{array}$ & $\begin{array}{c}\text { nil } \\
11-48-0 \\
33-0-0\end{array}$ & $\begin{array}{l}300 \\
100\end{array}$ & $\begin{array}{l}1.14 \\
2.00 \\
1.84\end{array}$ & $\begin{array}{l}161 \\
220 \\
206\end{array}$ \\
\hline $\begin{array}{l}\text { Bromegrass } \\
\text { plus alfalfa }\end{array}$ & $\begin{array}{c}\text { nil } \\
11-48-0 \\
33-0-0\end{array}$ & $\begin{array}{l}300 \\
100\end{array}$ & $\begin{array}{l}1.27 \\
2.09 \\
1.38\end{array}$ & $\begin{array}{l}165 \\
273 \\
170\end{array}$ \\
\hline
\end{tabular}

Experimental Farm, Beaverlodge 


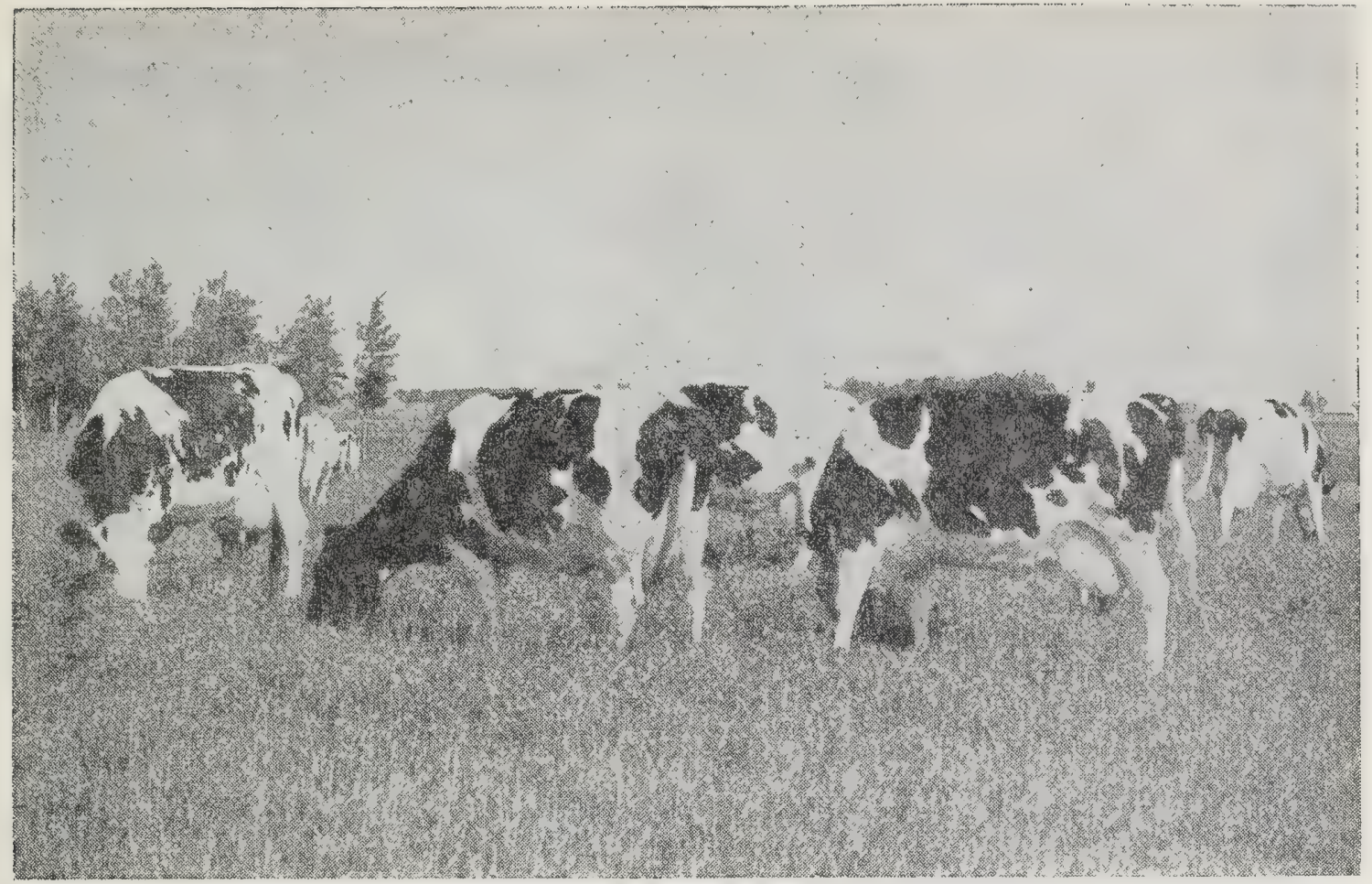

A dairy herd in the Edmonton milk-shed on a grass-legume pasture.

\section{Annual Pasture}

Annual pasture crops are useful for supplementing perennial pastures and for intensively grazed areas such as paddocks, hog pastures and poultry runs.

(1) Oats or oats and fall rye in mixture are favoured for annual pasture. The mixture is particularly valuable for hog pastures. When sowing a cereal for pasture, a heavier rate than normal should be used. Two bushels of oats and one bushel of fall rye, seeded in the spring, will, if not overgrazed, provide hog pasture in the summer and fall and again the following spring.

(2) Sow cereals in late May or early June so as to have them in the boot stage and ready to pasture by late July when other pastures are past their best.

(3) Cover crops, originally used to prevent soil drifting in southern Alberta, are now grown extensively for fall finishing of beef cattle in foothill areas where the annual rainfall is at least 18 inches. Oats seeded at $1 / 2$ to $3 / 4$ of a bushel per acre during the last half of July are the most satisfactory cover crop. Cattle are moved in when the oats are from 12 to 15 inches high. Average gains are $11 / 2$ to 2 pounds per animal per day, and gains as high as 3 pounds per day have been reported.

(4) The only annual forage, other than cereals, that has proven useful and economical in Alberta is rape (not to be confused with oil seed rape). It is useful as a pasture for hogs and lambs, it grows quickly and lambs make very good gains on it. Dwarf Essex rape, seeded at 4 to 5 pounds per acre, will normally be ready for grazing in six to seven weeks. One objection to rape for pasturing swine is that pigs tend to scald when running in it. 
Yields of Annual Forage Crops in Tons of Dry Matter per Acre at Lacombe, Alberta

(Three-year Averages, 1950-52)

\begin{tabular}{|l|c|c|}
\hline \multicolumn{1}{|c|}{ Crop and Rate of Seeding } & Hay & Pasture \\
\hline Eagle Oats (21/2 bu.) & 3.73 & 1.75 \\
Vantage barley (11/2 bu.) & 3.22 & $\ldots . .$. \\
Warrior barley (13/4 bu.) & 3.05 & $\ldots . .$. \\
Eagle oats (2 bu.) and Fall rye (1 bu.) & 3.13 & 1.90 \\
Fall rye (2 bu.) & $\ldots . .$. & 1.74 \\
Dwarf Essex Rape (5 lbs.) & $\ldots . .-$ & 1.67 \\
Eagle oats (2 bu.) \& Dwarf Essex Rape (3 lbs.) & $\ldots . . .-$ & 1.96 \\
\hline
\end{tabular}

Experimental Farm, Lacombe.

\section{MANAGEMENT OF HAY CROPS}

\section{Time of Cutting}

1. Cut hay early; while larger tonnages may be obtained by cutting later, actual feeding value and palatability will be less than if hay were cut in the proper stages.

For highest yields and feed value cut hay at the stages of growth indicated for the various crops:

\section{LEGUMES}

Alfalfa - - - - 1/10 bloom Red Clover - - - full bloom

Sweet Clover - - bud stage Alsike - - - - full bloom

\section{GRASSES}

Brome-Cut after heading, but before blooming.

Reed Canary, Crested Wheat, Timothy-should be cut when beginning to head for best quality.

Oats and other cereals-cut when grain is in soft dough stage.

2. Conserve the leaves-the greater part of the feed value is contained in the leaves. Rapid curing and careful handling will result in fewer leaves being lost.

3. Every effort should be made to put up hay that is of natural green color. Such hay is high in Vitamin A, an important part of a healthy diet for animals on winter feed. Rain on hay not only causes loss of Vitamin A but other water soluble nutrients are also lost. Cut no more hay than can be handled quickly.

Small windrows allow air circulation and more rapid curing.

Hay can be left longer in the swath when a side delivery rake is used as less leaves are lost through its action than with the conventional rake. 


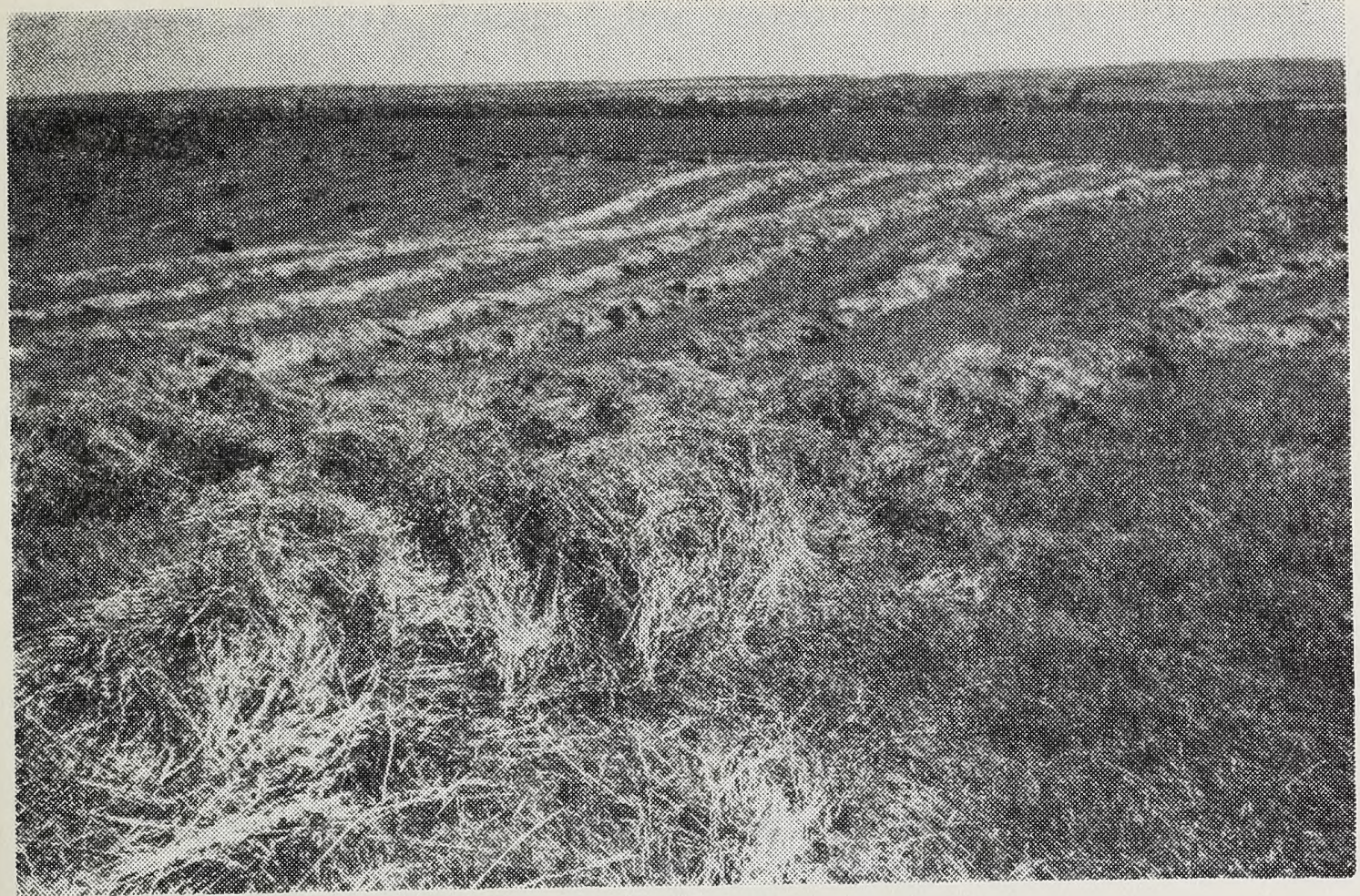

A brome alfalfa hay mixture in windrow

Photo-Lacombe Experimental Farm

\section{Storage of Hay}

Hay must be below $25 \%$ moisture for storage in the stack. A rough guide for farmers to use to determine whether the hay is dry enough to store is to twist a wisp of hay in the hands. If the twisted hay is tough and there is evidence of moisture where the stems are broken, the hay is too tough for safe storage. If the stems are slightly brittle when broken and there is no evidence of moisture when the stems are twisted, the hay can be stored without danger of spoilage.

Moisture content of hay for baling must be lower than for loose storing and hay for chopping should be below 20\%. Keep in mind that baled hay will occupy only $1 / 2$ the space that would be occupied by the same weight of loose hay and chopped hay occupies only $1 / 3$ of the space. If a barn mow is to be filled with chopped hay make sure it is well braced.

\section{Silage}

In areas where it is difficult to put hay up in good conditions, silage may be an answer. Silage can be handled mechanically and harvested during weather that is unfit for haying without serious losses in feed value. Many livestock producers have found it practical to install self feeding gates in trench silos, thereby reducing handling to a minimum. 
Other Publications on Grasses and Legumes Available From:

Extension Service, Alberta Department of Agriculture-

Circular 79-Grass and Legume Seed Crops in Alberta.

Publication 108-Grass Silage for Alberta.

Publication 22-Hay and Pasture Mixtures for Alberta.

Department of Extension, University of Alberta-Edmonton-

Bulletin 44-Cropping for Profit and Permanency.

Circular 4-Legume Inoculation.

Information Service, Dominion Department of Agriculture-Ottawa-

Mimeograph-Growing Crested Wheat Grass for Seed Production.

Publication 753-Hay Making With Crested Wheat Grass in the Dry Areas of Alberta.

Publication 557-Crested Wheat Grass for Hay and Pasture.

Publication 693-Improved Pasture Crops and Pasture Practices for Central Alberta.

Publication 866-Brome Grass Seed Production in Western Canada.

Publication 860-Annual Crops for Hay and Pasture.

Information can also be obtained from your District Agriculturist; the Field Crops Branch, Alberta Department of Agriculture; Departments of Plant Science and Soil, University of Alberta; or from your nearest Experimental Farm. 


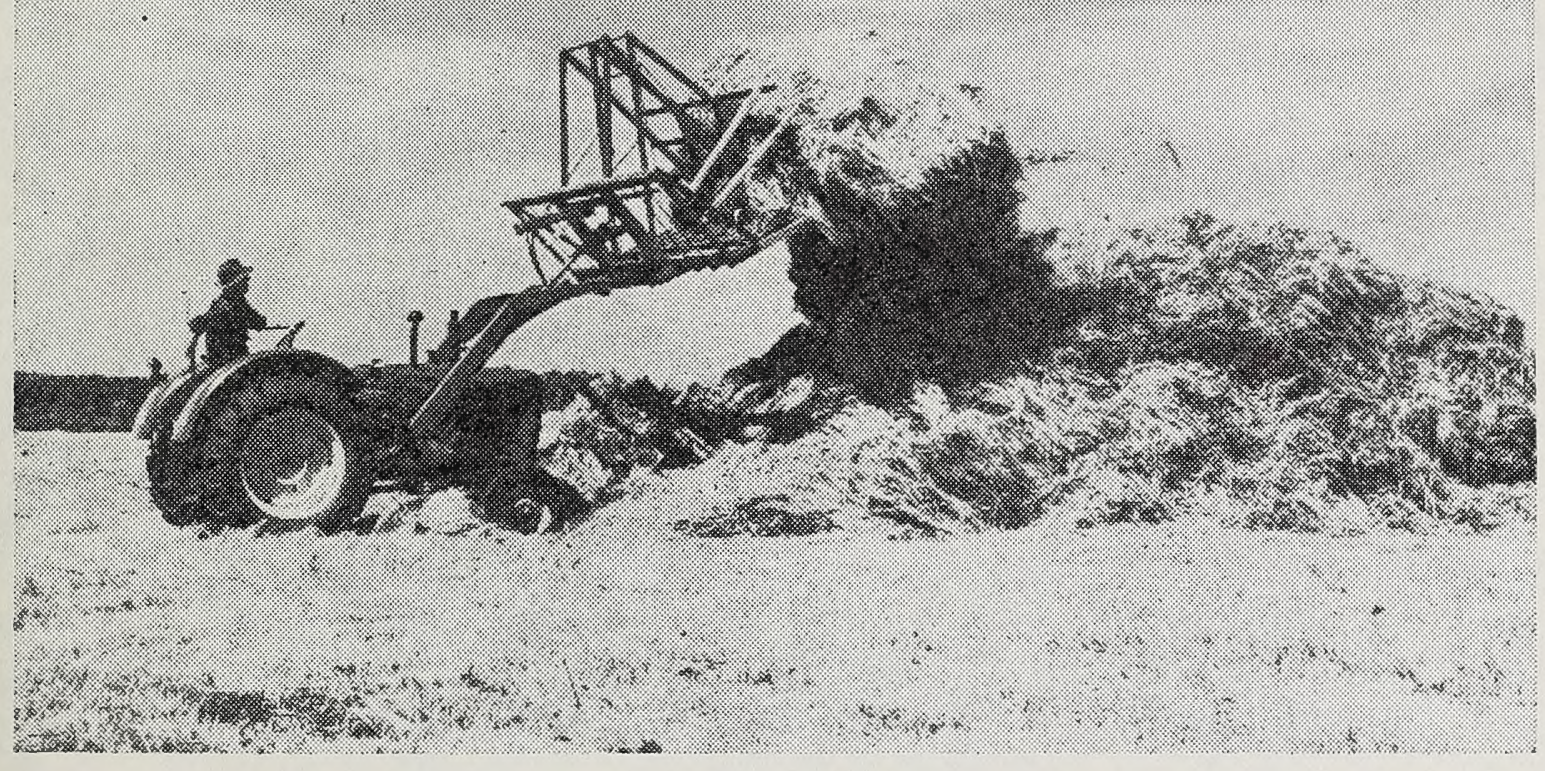

Mechanical equipment saves time and labour during the hay season.

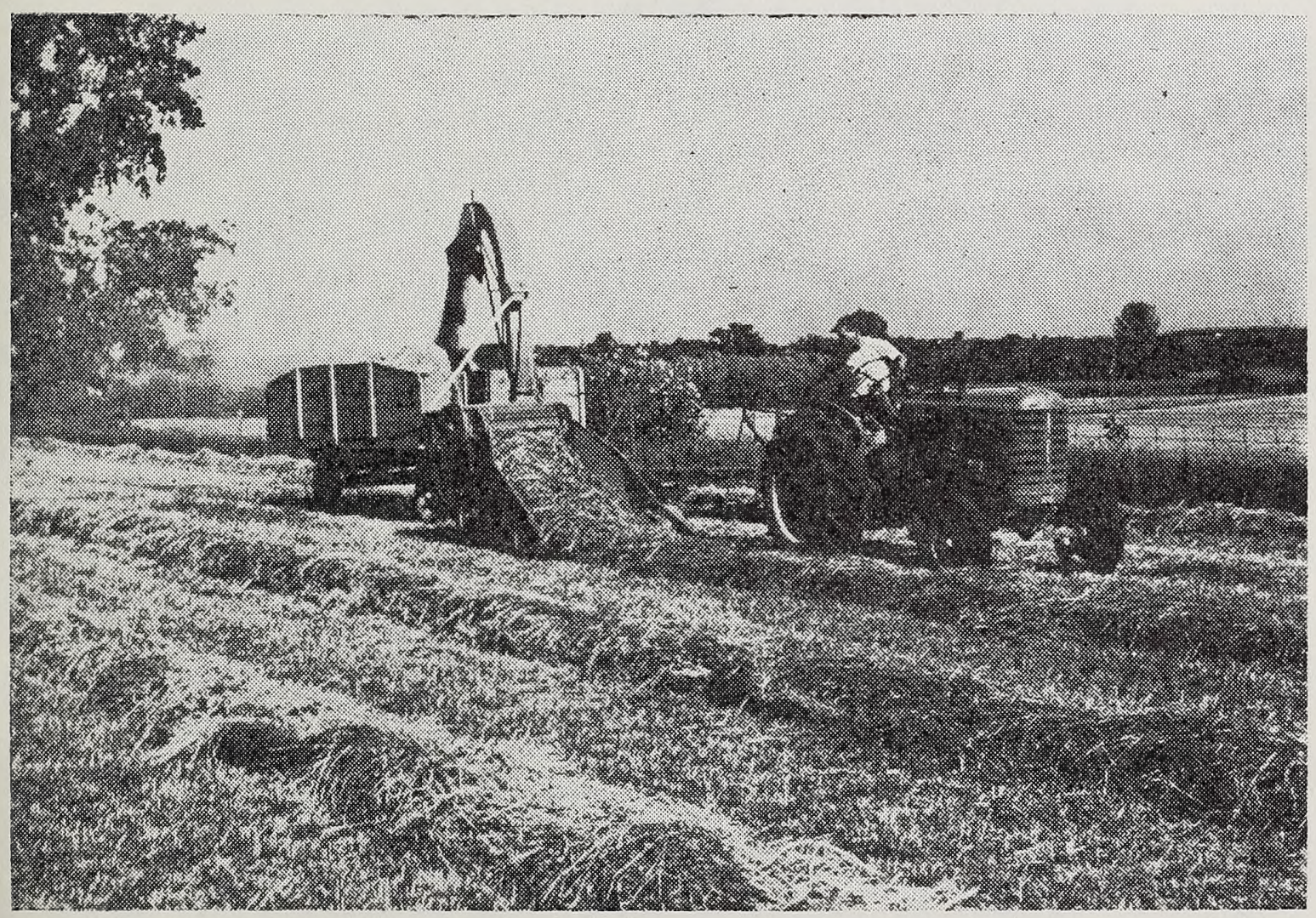

Field chopping a grass legume mixture for silage. 


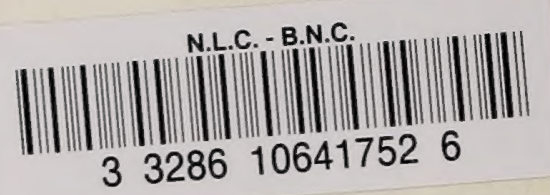

EDMONTON, ALBERTA

Printed by L. S. WALL, Printer to the Queen's Most Excellent Majesty 1957 